Louisiana State University

LSU Digital Commons

$8-1-2004$

\title{
Low levels of nucleotide diversity in Crocodylus moreletii and evidence of hybridization with $\mathrm{C}$. acutus
}

\author{
David A. Ray \\ Texas Tech University \\ Jennifer A. Dever \\ University of San Francisco \\ Steven G. Platt \\ Wildife Conservation Society \\ Thomas R. Rainwater \\ Texas Tech University \\ Adam G. Finger \\ Texas Tech University
}

See next page for additional authors

Follow this and additional works at: https://digitalcommons.Isu.edu/biosci_pubs

\section{Recommended Citation}

Ray, D., Dever, J., Platt, S., Rainwater, T., Finger, A., McMurry, S., Batzer, M., Barr, B., Stafford, P., McKnight, J., \& Densmore, L. (2004). Low levels of nucleotide diversity in Crocodylus moreletii and evidence of hybridization with C. acutus. Conservation Genetics, 5(4), 449-462. https://doi.org/10.1023/ B:COGE.0000041024.96928.fe 


\section{Authors}

David A. Ray, Jennifer A. Dever, Steven G. Platt, Thomas R. Rainwater, Adam G. Finger, Scott T. McMurry, Mark A. Batzer, Brady Barr, Peter J. Stafford, Jenna McKnight, and Llewellyn D. Densmore 


\title{
Low levels of nucleotide diversity in Crocodylus moreletii and evidence of hybridization with $C$. acutus
}

\author{
David A. Ray ${ }^{1,5, *}$, Jennifer A. Dever ${ }^{2}$, Steven G. Platt ${ }^{3,}$, Thomas R. Rainwater ${ }^{4}$, \\ Adam G. Finger ${ }^{4}$, Scott T. McMurry ${ }^{4}$, Mark A. Batzer ${ }^{5}$, Brady Barr ${ }^{6}$, Peter J. Stafford ${ }^{7}$, \\ Jenna McKnight ${ }^{8} \&$ Llewellyn D. Densmore ${ }^{1}$ \\ ${ }^{1}$ Department of Biological Sciences, MS 3131, Texas Tech University, Lubbock, TX, 79409, USA; ${ }^{2}$ Uni- \\ versity of San Francisco, Harney Science Center, Room 342, 2130 Fulton St., San Francisco, CA 94117, \\ USA; ${ }^{3}$ Wildlife Conservation Society, 2300 Southern Blvd., Bronx, NY, 10460-1099,US; ${ }^{4}$ The Institute of \\ Environmental and Human Health, Box 41163, Texas Tech University, Lubbock, TX 79409-1163, USA; \\ ${ }^{5}$ Department of Biological Sciences, Louisiana State University, 202 Life Sciences Building, Baton Rouge, \\ LA, 70803, USA; ${ }^{6}$ National Geographic Society, 1145 17th St. NW, Washington, DC, 20036, USA; ${ }^{7}$ The \\ Natural History Museum, Cromwell Road, London SW7 5BD, UK; ${ }^{8}$ Department of Biology, University of \\ Miami, Coral Gables, FL 33124, USA (Current addresses: ${ }^{*}$ Oglala Lakota College, P.O. Box 490, Kyle, SD, \\ 57752, USA) (*Author for correspondence,e-mail: daray@lsu.edu; fax: +1-225-578-7105)
}

Received 22 July 2003; accepted 24 January 2004

Key words: Crocodylus, D-loop, hybridization, mtDNA, phylogeography

\begin{abstract}
Examinations of both population genetic structure and the processes that lead to such structure in crocodilians have been initiated in several species in response to a call by the IUCN Crocodile Specialist Group. A recent study used microsatellite markers to characterize Morelet's crocodile (Crocodylus moreletii) populations in north-central Belize and presented evidence for isolation by distance. To further investigate this hypothesis, we sequenced a portion of the mitochondrial control region for representative animals after including samples from additional locales in Belize, Guatemala and Mexico. While there is limited evidence of subdivision involving other locales, we found that most of the differentiation among populations of C. moreletii can be attributed to animals collected from a single locale in Belize, Banana Bank Lagoon. Furthermore, mitochondrial DNA sequence analysis showed that animals from this and certain other locales display a haplotype characteristic of the American crocodile, C. acutus, rather than C. moreletii. We interpret this as evidence of hybridization between the two species and comment on how these new data have influenced our interpretation of previous findings. We also find very low levels of nucleotide diversity in $C$. moreletii haplotypes and provide evidence for a low rate of substitution in the crocodilian mitochondrial control region. Finally, the conservation implications of these findings are discussed.
\end{abstract}

\section{Introduction}

The International Union for the Conservation of Nature and Natural Resources (IUCN) Crocodile Specialist Group (CSG) recently emphasized the need for population genetic surveys of several crocodilian species, including some considered to be critically endangered (Ross 1998). The objectives of these surveys are to obtain basic information on phylogeography, population structure and migration patterns, to gather data on paternity patterns and the related issues of sperm storage and sperm competition, and to examine suspected introgression from widespread 
crocodilians into the genomes of more restricted species (e.g., invasion by the American crocodile [Crocodylus acutus] into Cuban crocodile [C. rhombifer] habitat and resulting hybridization, see Ramos et al. 1994). This information can be used to implement more effective conservation strategies for crocodilians.

Microsatellite data have been informative in accomplishing several of these goals. Examination of microsatellite loci in American alligator (Alligator mississippiensis) populations has documented population structure (Glenn et al. 1998, Davis et al. 2001a) and demonstrated multiple paternity (Davis et al. 2001b). Microsatellites developed for the genus Crocodylus by FitzSimmons et al. (2001) have the potential to be at least as useful. These loci not only amplify DNA in many crocodilian species, but are often highly variable (Dever and Densmore 2001). These loci have also been used to identify captive hybrids of $C$. rhombifer, the Siamese crocodile (C. siamensis), and the Estuarine crocodile (C. porosus) to prevent their re-introduction to the wild (FitzSimmons et al. 2002).

In contrast, mitochondrial DNA (mtDNA) sequence data sets have not been extensively employed in population-level studies of crocodilians. Most studies using mitochondrial data sets have focused on phylogenetic questions rather than population structure or phylogeography (Densmore and Owen 1989; Densmore and White 1991; Gatesy and Amato 1992; Ray et al. 2001). This is somewhat surprising since the population structure of many other vertebrates have been examined using DNA sequences from coding (Donovan et al. 2000; Fleischer et al. 2001; Hoffman and Baker 2001; Kotlik and Berrebi 2001; Nielson et al. 2001), and non-coding regions of the mitochondrial genome (Lahanas et al. 1994; Walker and Avise 1998; Cicero and Johnson 1998; Barrowclough et al. 1999; Roman et al. 1999; Vila et al. 1999; Milot et al. 2000; Rooney et al. 2001; Jensen-Seaman and Kidd 2001; Dawson et al. 2001). The non-coding sequences are often shown to be the most variable portion of the genome (McMillan and Palumbi 1997; Baker and Marshall 1997; but also see Randi and Lucchini 1998; Crochet and Desmarais 2000), suggesting that the control region may be a useful marker for studies of crocodilian populations.

Recently, Glenn et al. (2002) published data examining mitochondrial control region haplotype distributions in A. mississippiensis. They found a very low level of nucleotide diversity - only three haplotypes spread across the southeastern United States. These data fit a well-documented trend of low levels of molecular variation for several markers (Gartside et al. 1977; Menzies et al. 1979; Adams et al. 1980; Glenn et al. 1998), but contradict the most recent analyses with microsatellites (Davis et al. 2002). A potential weakness of this study is that only 25 individuals were examined (Glenn et al. 2002). For researchers to accurately judge the levels of mtDNA variation that are expected in crocodilian populations, studies of other species and larger sample sizes are required.

Morelet's crocodile (Crocodylus moreletii) is one of two crocodile species to occur in Mexico, Guatemala, and Belize. C. moreletii typically inhabits freshwater wetland habitats while C. acutus is restricted to coastal mainland habitats and offshore islands (Platt 1996; Platt and Thorbjarnarson 2000a,b). Both species were subjected to extensive hunting pressures during the middle of the 20th century leading to drastic population declines (Charnock-Wilson 1970; Platt 1996; Platt and Thorbjarnarson 2000a,b; Ross 1998). Both are currently considered endangered by the IUCN and listed on Appendix I of CITES (Platt and Thorbjarnarson 2000a,b; Ross 1998).

Dever et al. (2002) initiated a population genetic analysis of $C$. moreletii in Belize using microsatellite markers in order to assess the genetic variability of Morelet's crocodile. Results of this study demonstrated levels of genetic variation in north-central Belize (average $H_{\mathrm{O}}=0.49$ ) comparable to the American alligator and revealed evidence for some population substructure $\left(R_{\mathrm{ST}}=0.1\right)$. The structure observed was primarily due to the inclusion of animals from a single small population found in Banana Bank Lagoon near the Belize River at the southern end of the sampled range. Dever et al. (2002) suggested that the observed data could support an isolation by distance model of gene flow (Wright 1978).

Our study expanded on Dever et al. (2002) by incorporating mitochondrial control region sequence data for a representative subsample of the animals originally examined and for additional animals from several more distant locales, including southern Belize, Mexico and Guatemala $(n=140)$. Our objectives were to (1) examine intraspecific variation within the mitochondrial 
control region and investigate its utility as a phylogeographic marker using Crocodylus moreletii as a model and (2) use the mitochondrial data to evaluate the hypothesis proposed by Dever et al. (2002) that Morelet's crocodile populations follow an isolation-by-distance model of genetic differentiation. After collecting preliminary data, we noted several individuals bearing haplotypes closely resembling those found in $C$. acutus than in $C$. moreletii. Thus, we examined $C$. moreletii populations for evidence of hybridization with C. acutus by identifying haplotype differences.

\section{Methods}

\section{Sampling and data collection}

As part of continuing studies of Morelet's crocodile populations, we have sampled several locales (Figure 1) previously reported by Dever et al. (2002). We also sampled crocodiles at two additional sites in Belize: Crooked Tree Wildlife Sanctuary and the Macal River. All new samples were collected during the spring and summer of 2001 and 2002 using the methods described in
Dever and Densmore (2001). Sample sizes for each locale can be found in Table 1. Total genomic DNA was extracted from blood samples using the Gentra Puregene isolation kit (Gentra Systems, Minneapolis, MN). Total genomic DNA was also isolated from skin clips of animals captured in the states of Peten, Guatemala and Tabasco, Mexico, using standard PCI protocols (Sambrook et al. 1989). For outgroup comparisons, control region sequences from the American crocodile (Crocodylus acutus), the Orinoco crocodile (C. intermedius), the Cuban crocodile (C. rhombifer), and the Nile crocodile (C. niloticus) were obtained from GenBank (accession numbers AF460218, AF460207, AF460214 and AF460211, respectively).

Amplification of an 540 bp DNA fragment (starting $6 \mathrm{bp}$ within the tRNA-Pro gene and ending just $3^{\prime}$ of CSB-1 in domain III of the mitochondrial control region) was performed using protocols and primers as previously described in Ray and Densmore (2002). Following amplification, PCR products were purified using the Qiagen PCR purification kit (Qiagen Inc., Valencia CA). Chain termination sequencing reactions were performed on both strands using the PCR primers and chromatograms were

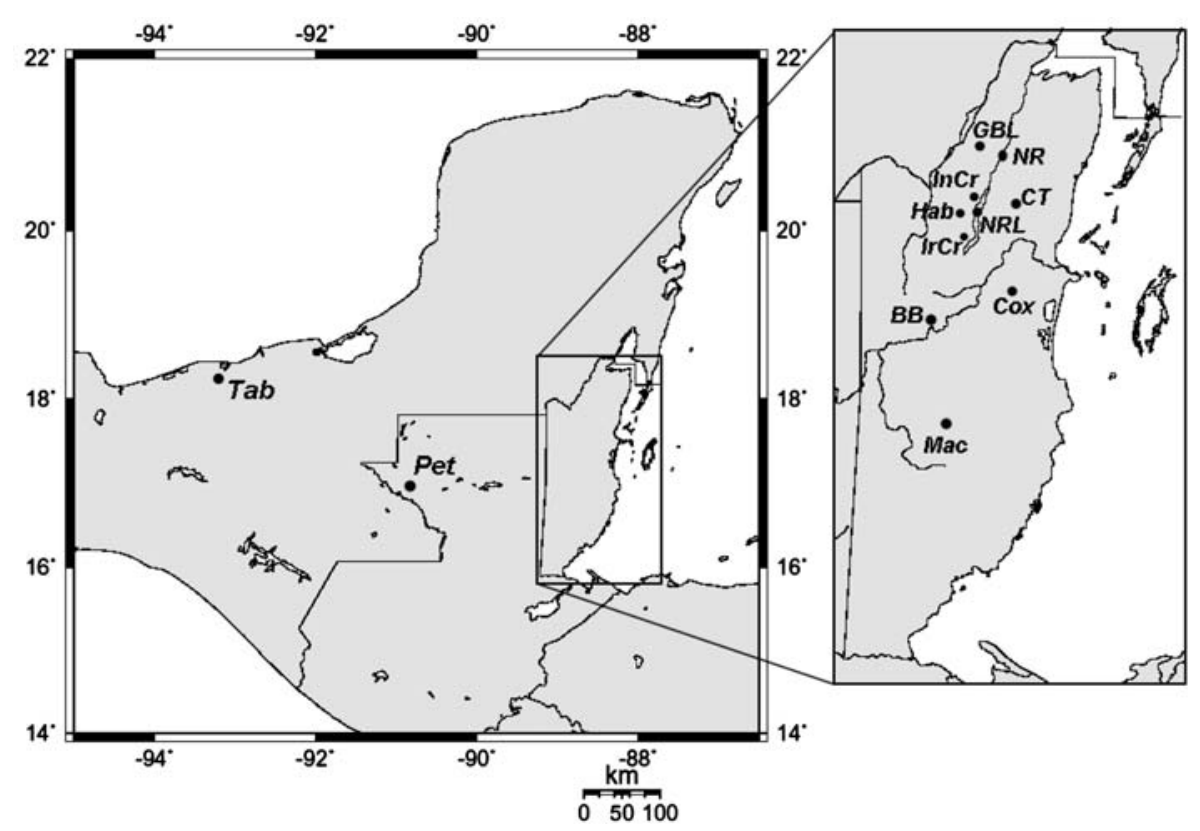

Figure 1. Map of sampling locales. $\mathrm{BB}=$ Banana Bank Lagoon, Cox $=$ Cox Lagoon, $\mathrm{CT}=$ Crooked Tree Wildlife Sanctuary, $\mathrm{GBL}=$ Gold Button Lagoon, $\mathrm{Hab}=$ Habanero Lagoon, $\mathrm{InCr}=$ Indian Creek, $\mathrm{IrCr}=\mathrm{Irish}$ Creek, $\mathrm{Mac}=\mathrm{Macal}$ River, NR $=\mathrm{New}$ River, NRL = New River Lagoon, Pet = Peten, Guatemala, Tab = Tabasco, Mexico. 
Table 1. Haplotype distribution for mtDNA control region sequences

\begin{tabular}{|c|c|c|c|c|c|c|c|c|c|c|c|c|}
\hline \multirow[t]{2}{*}{ Haplotype } & \multicolumn{12}{|c|}{ Sample location } \\
\hline & $\begin{array}{l}\text { BB } \\
\text { (17) }\end{array}$ & $\begin{array}{l}\text { Cox } \\
\text { (6) }\end{array}$ & $\begin{array}{l}\text { CT } \\
\text { (3) }\end{array}$ & GBL (13) & $\begin{array}{l}\text { Hab } \\
\text { (11) }\end{array}$ & $\operatorname{InCr}(3)$ & $\begin{array}{l}\mathrm{IrCr} \\
(5)\end{array}$ & $\begin{array}{l}\text { Mac } \\
\text { (11) }\end{array}$ & NR (23) & $\begin{array}{l}\text { NRL } \\
(38)\end{array}$ & $\begin{array}{l}\text { Pet } \\
(5)\end{array}$ & $\begin{array}{l}\text { Tab } \\
(5)\end{array}$ \\
\hline A & 2 & 5 & 2 & 13 & 9 & 1 & 2 & 9 & 19 & 29 & 2 & 4 \\
\hline$B$ & 14 & - & - & - & - & 2 & 2 & - & - & 4 & - & - \\
\hline C & - & - & - & - & - & - & - & - & - & 2 & - & - \\
\hline$D$ & 1 & - & - & - & - & - & - & - & - & - & - & - \\
\hline E & - & 1 & - & - & - & - & - & - & - & - & - & - \\
\hline $\mathrm{F}$ & - & - & 1 & - & - & - & - & - & - & - & - & - \\
\hline G & - & - & - & - & 1 & - & - & - & - & - & - & - \\
\hline $\mathrm{H}$ & - & - & - & - & 1 & - & - & - & - & - & - & - \\
\hline I & - & - & - & - & - & - & 1 & - & - & - & - & - \\
\hline $\mathrm{J}$ & - & - & - & - & - & - & - & 1 & - & - & - & - \\
\hline $\mathrm{K}$ & - & - & - & - & - & - & - & 1 & - & - & - & - \\
\hline $\mathrm{L}$ & - & - & - & - & - & - & - & - & 1 & - & - & - \\
\hline M & - & - & - & - & - & - & - & - & 1 & - & - & - \\
\hline $\mathrm{N}$ & - & - & - & - & - & - & - & - & - & 1 & - & - \\
\hline $\mathrm{O}$ & - & - & - & - & - & - & - & - & - & 1 & - & - \\
\hline$P$ & - & - & - & - & - & - & - & - & - & 1 & - & - \\
\hline Q & - & - & - & - & - & - & - & - & - & - & 1 & - \\
\hline $\mathrm{R}$ & - & - & - & - & - & - & - & - & - & - & 1 & - \\
\hline $\mathrm{S}$ & - & - & - & - & - & - & - & - & - & - & 1 & - \\
\hline $\mathrm{T}$ & - & - & - & - & - & - & - & - & - & - & - & 1 \\
\hline
\end{tabular}

Sample sizes from each locale are indicated in parentheses.

obtained using ABI 310 and 3100 genetic analyzers. Sequences were visualized, aligned and edited with the program BioEdit (Hall 1999). All sequences have been added to GenBank under accession numbers AY136686-AY136738 and AY341444-AY341530. Haplotype definitions and distributions have been deposited at the Population Genetics Database (http://seahorse.louisiana.edu/PGDB/).

\section{Data analysis}

PAUP* v4.0b10 (Swofford 1998) was used to generate HKY85 (Hasegawa et al. 1985) genetic distances for the mtDNA sequences as suggested by a likelihood ratio test implemented using Modeltest 3.06 (Posada and Crandall 1998) We employed Arlequin v2.000 (Schneider et al. 2000) to perform analyses of haplotype frequencies, to obtain estimates of $F_{\mathrm{ST}}$, to perform tests of population subdivision via AMOVA, and to perform Mantel's tests (Mantel 1967) with both distance and $F_{\mathrm{ST}}$ estimates. Arlequin also was used to perform mismatch analyses (Rogers and Harpending 1992), and to estimate haplotype and nucleotide diversities (Nei 1987, p.180 and 257). A median-joining network of haplotypes was constructed using Network (Bandelt et al. 1999, www.fluxus-engineering.com)

\section{Results}

One hundred forty initial mtDNA control region sequences ranging from 534 to 537 bp were obtained. The relative lack of insertion/deletion events (6) made alignment of the sequences straightforward. Among the crocodiles sampled, there were 45 polymorphic sites and 20 unique haplotypes (A-T). A median joining analysis of the haplotypes yielded a network that clearly clusters the haplotypes into two clades separated by 21 sequence changes (Figure 2). Haplotypes in clade 2 are primarily from animals collected at 


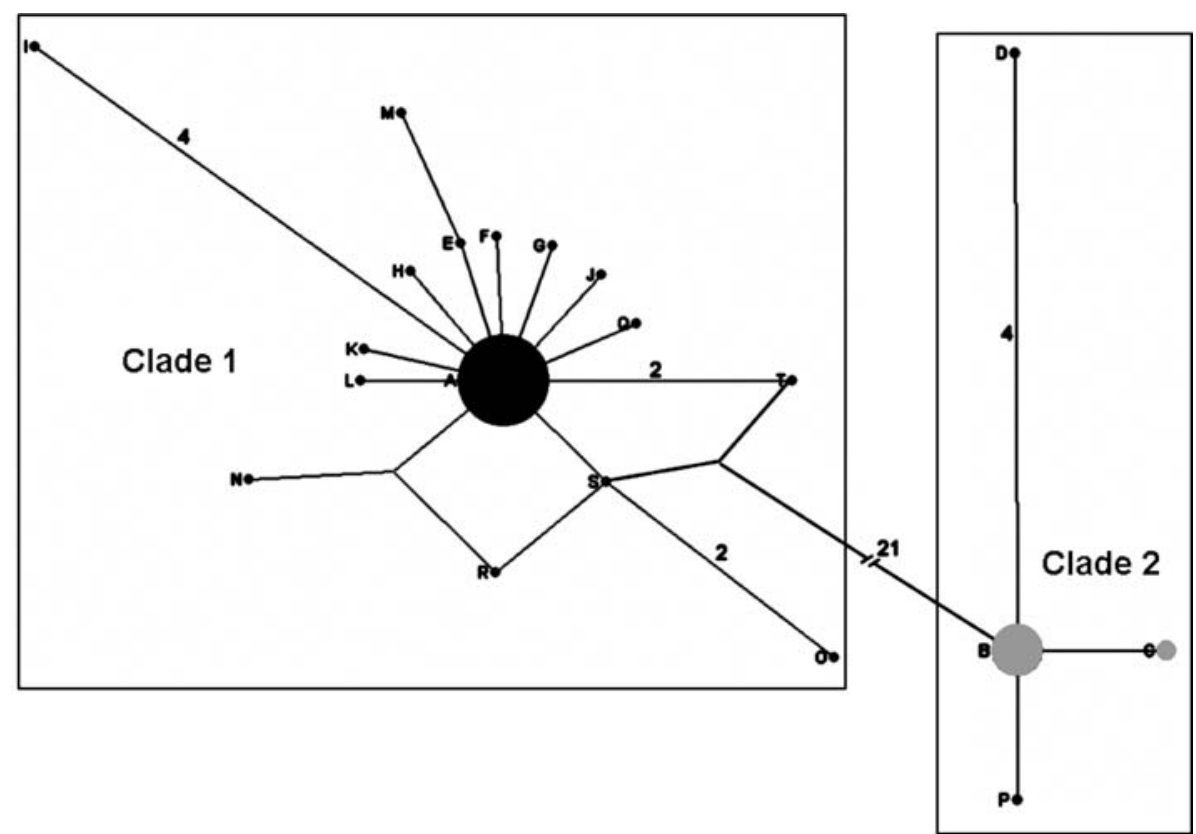

Figure 2. Median-joining network of C. moreletii-like and C. acutus-like haplotypes.Connections between haplotypes indicate single sequence differences unless otherwise indicated.

Banana Bank Lagoon, but this clade is also comprised of samples from New River, New River Lagoon and Indian Creek.

Other crocodylian control region sequences ranged from $533 \mathrm{bp}$ in Crocodylus niloticus to 534 bp in both $C$. intermedius and $C$. rhombifer to $536 \mathrm{bp}$ in C. acutus. The inclusion of outgroup taxa in a neighbor-joining tree of unique haplotypes (Figure 3) strongly suggested that all of the haplotypes present in clade 2 had originated in C. acutus and not C. moreletii (bootstrap $=95 \%$ ). This was verified by incorporating ten additional sequences from $C$. acutus (accession numbers AY568308-AY568317). These sequences, obtained from animals originating from the west coast of Mexico to Florida were not substantially different from the original C. acutus reference sequence - five haplotypes (U-Y) with an average of 1.82 differences between them. Therefore, we designated each unique haplotype as either $C$. moreletii-like or C. acutus-like.

The average HKY85 genetic distance estimate among all unique $C$. moreletii-like haplotypes was $0.0062 \pm 0.0087$, and among all C. acutus-like haplotypes was $0.0048 \pm 0.0040$. The average genetic distance between acutus-like and moreletiilike unique haplotypes was $0.0553 \pm 0.0049$.
When each haplotype was examined for geographic distribution (Table 1), one, A, was found to be present in all sampled locales. Haplotype A was found at a high frequency $(\geq 0.40)$ in all locales except Banana Bank Lagoon where haplotype B (C. acutus-like) predominated. The remaining haplotypes were, for the most part, single examples scattered throughout the range. Within-population haplotype diversity ranged from zero at Gold Button Lagoon to $0.413 \pm 0.097$ in New River Lagoon (Table 2). Overall haplotype diversity $(h)$ for the 140 original samples was $0.502 \pm 0.048$ and $0.251 \pm 0.055$ for C. moreletiilike haplotypes only. Overall nucleotide diversity $(\pi)$ was $0.013 \pm 0.007$ and $0.00072 \pm 0.00073$ for C. moreletii-like haplotypes.

After incorporating all individuals for which control region sequence was available, our estimate of $F_{\mathrm{ST}}$ was 0.28 (see Table 3 for complete $F_{\mathrm{ST}}$ listings). We suspected, however, that any population genetic structure found that involved the Banana Bank population may have resulted from either invasion of $C$. acutus into habitat considered typical of $C$. moreletii and subsequent misidentification of these animals or from the inclusion of C. Moreletii-C. acutus hybrids in our sample. Therefore, we performed two sets of analyses on 


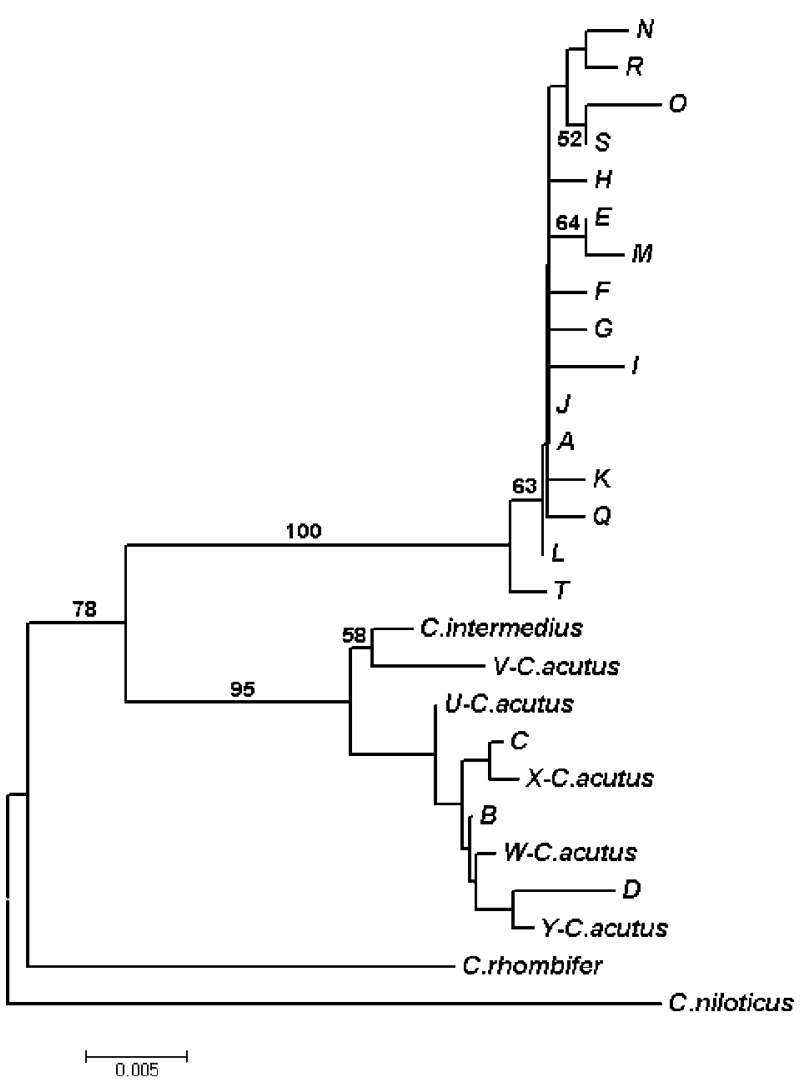

Figure 3. Neighbor-joining tree of unique haplotypes and outgroup sequences generated using HKY85 genetic distances. Numbers at nodes indicate bootstrap values (1000 replicates)

Table 2. Haplotype $(h)$ and nucleotide $(\pi)$ diversity estimates for $C$. moreletii mtDNA control region sequences

\begin{tabular}{lll}
\hline Locale $^{\mathrm{a}}$ & \multicolumn{2}{l}{ All data } \\
\cline { 2 - 3 } & Haplotype diversity & Nucleotide diversity \\
\hline Banana Bank & $0.324 \pm 0.136$ & $0.0091 \pm 0.0045$ \\
Cox Lagoon & - & - \\
Crooked Tree & - & - \\
Gold Button Lagoon & 0 & 0 \\
Habenero & $0.346 \pm 0.172$ & $0.0007 \pm 0.0004$ \\
Indian Creek & - & - \\
Irish Creek & - & - \\
Macal River & $0.182 \pm 0.021$ & $0.0003 \pm 0.0003$ \\
New River & $0.324 \pm 0.124$ & $0.0064 \pm 0.0036$ \\
New River Lagoon & $0.413 \pm 0.097$ & $0.0123 \pm 0.0031$ \\
Peten, Guat. & - & - \\
Tabasco, Mex. & - & - \\
Overall & $0.502 \pm 0.048$ & $0.251 \pm 0.055$ \\
\hline
\end{tabular}

${ }^{\text {a }}$ Locales with $n<10$ are excluded from individual estimates of diversity but included in overall 
Table 3. Pairwise estimates of $F_{\mathrm{ST}}$ for sampled populations

\begin{tabular}{llllllllllllll}
\hline & BB & Cox & CT & GBL & Hab & InCr & IrCr & MR & NR & NRL & Pet & Tab \\
\hline Banana Bank Lag. & - & -0.304 & -0.200 & 0.000 & -0.276 & 0.000 & -0.200 & -0.276 & -0.308 & -0.317 & -0.017 & -0.290 \\
Cox Lagoon & 0.638 & - & -0.059 & 0.139 & -0.068 & -1.000 & -0.059 & -0.068 & -0.021 & 0.029 & 0.094 & -0.097 \\
Crooked Tree & 0.568 & -0.059 & - & 0.490 & -0.024 & -1.000 & -0.200 & -0.024 & 0.156 & 0.283 & -0.090 & -0.104 \\
Gold Button Lag. & 0.795 & 0.139 & 0.490 & - & 0.069 & 0.000 & 0.490 & 0.069 & -0.004 & -0.021 & 0.481 & 0.207 \\
Habanero Lag & 0.632 & -0.068 & -0.024 & 0.069 & - & -0.900 & -0.024 & -0.045 & -0.010 & 0.027 & 0.141 & -0.071 \\
Indian Creek & -0.102 & 0.372 & 0.143 & 0.817 & 0.398 & - & -1.000 & -0.900 & -0.950 & -0.967 & -0.500 & -1.000 \\
Irish Creek & 0.188 & 0.167 & -0.014 & 0.558 & 0.210 & -0.235 & - & -0.024 & 0.156 & 0.283 & -0.090 & -0.104 \\
Macal River & 0.632 & -0.068 & -0.024 & 0.069 & -0.045 & 0.398 & 0.210 & - & -0.010 & 0.027 & 0.141 & -0.071 \\
New River & 0.626 & -0.053 & 0.016 & 0.029 & -0.032 & 0.417 & 0.245 & -0.032 & - & -0.015 & 0.333 & 0.002 \\
New River Lag. & 0.541 & 0.038 & -0.020 & 0.060 & -0.014 & 0.292 & 0.152 & -0.014 & -0.017 & - & 0.451 & 0.069 \\
Peten, Guatemala & 0.467 & 0.094 & -0.090 & 0.481 & 0.141 & 0.073 & -0.012 & 0.141 & 0.202 & 0.151 & - \\
Tabasco, Mexico & 0.619 & -0.097 & -0.104 & 0.207 & -0.071 & 0.311 & 0.118 & -0.071 & -0.053 & -0.046 & 0.044 & - \\
\hline
\end{tabular}

Estimates incorporating all sequences are located below the diagonal. Estimates above the diagonal were calculated after removing C. acutuslike haplotypes. Estimates with $P$-values $\leq 0.05$ are italicized.

the data set. One set incorporated all data from every animal collected. The second set of analyses involved the removal of any samples in which the C. acutus-like haplotype had been identified. This dual pattern of data analysis is discussed in each relevant table and will be followed for the remainder of the paper. An unfortunate consequence of removing individuals bearing the C. acutus-like haplotype from the second set of analyses was to substantially reduce sample sizes at Banana Bank Lagoon (from 17 to 2), Irish Creek (5 to 3), and Indian Creek (3 to 1). Individuals from New River and New River Lagoon were also removed but sample sizes remained reasonable (21 and 31, respectively).

Removing individuals with $C$. acutus-like haplotypes reduced $F_{\mathrm{ST}}$ to 0.06 but three population pairs remained that continued to show high pairwise $F_{\mathrm{ST}}$ values. Comparisons between the Peten, Guatemala population and New River, New River Lagoon, and Gold Button Lagoon were significantly different from those expected under a null hypothesis of no population differentiation when C. acutus-like haplotypes are not considered. Values ranged from 0.333 (NR versus Peten, $P=0.028$ ) to 0.481 (GBL versus Peten, $P=0.010)$.

An examination of the possible correlation between genetic and geographic distances using Mantel test and incorporating all sequences did not support a model of isolation by distance (correlation coefficient $(r)=-0.137$, $P=0.750$ ). While removing $C$. acutus-like haplotypes from analyses of populations increased the correlation between geography and genetic similarity, results were not significant $(r=.0918$, $P=0.334)$.

\section{Discussion}

\section{Diversity estimates}

This study represents only the second analysis of crocodilian mitochondrial control region DNA to be performed from a population genetic perspective. It is also the first to use mtDNA as a tool for such studies in a member of Crocodylus. The only previous examination of a crocodilian was performed by Glenn et al. (2002) for the American alligator. In that study, levels of haplotype and nucleotide variation in $A$. mississippiensis were low ( $h=0.313, \pi=0.00034$ ). Our estimates of nucleotide diversity are twice as high as those reported by Glenn et al. (2002) but, with the exception of some turtles (Avise et al. 1992; Lahanas et al. 1994; Encalada et al. 1996; Roman et al. 1999), are still very low in comparison to estimates in other vertebrates (Cicero and Johnson 1998; Barrowclough et al. 1999; Vila et al. 1999; Milot et al. 2000; Dawson et al. 2001; Jensen-Seaman and Kidd 2001). Nucleotide diversity increases to levels 
comparable to other vertebrates only when C. acutus-like haplotypes are included.

The distribution of $A$. mississippiensis is more extensive than that of C. moreletii and thus greater nucleotide variation in the alligator might be expected. However, as Glenn et al. (2002) suggested, a population bottleneck $21,000 \pm 1500$ years ago (Jackson 2000; Waters et al. 2000) may have played a role in reducing nucleotide diversity since the lower effective population size of mtDNA would impact this genome more severely than the nuclear genome (Maruyama and Fuerst 1984, 1985). The pattern of variation found at polymorphic microsatellite loci in C. moreletii (Dever et al. 2002) is similar to that found in American alligators (Glenn et al. 1998) in that there are high levels of variation at polymorphic loci, an observation consistent with the hypothesis of a recent bottleneck.

The mismatch distribution calculated from the mitochondrial sequence data, however, does not support the bottleneck scenario (Figure 4). The plot for only C. moreletii-like data is consistent with a population that has been at equilibrium in the recent past (cf. Figure 2 of Rogers and Harpending 1992) and thus suggests that a population bottleneck similar to the one hypothesized for A. mississippiensis is unlikely. Adding haplotypes characteristic of the American crocodile causes the plot to mimic those encountered when there is incomplete lineage sorting. It is indeed possible that paraphyly caused by the retention of two haplotypes which were characteristic of the common ancestor of both C. acutus and C. moreletii exists in C. moreletii (see Funk and Omland 2003). We do not discount this scenario. However, it is clear that this level of sequence divergence (5.53\%) is more typical of comparisons between well-defined species of Crocodylus (avg. HKY85 divergence $=6.46 \%$; see Table 4 and Ray et al. 2001).

Another possibility is that a recent event has reduced the nucleotide diversity via a selective sweep or some other event that mimics the effect of a sweep. This is a difficult hypothesis to test but we would expect that such a process would result in a mismatch distribution which mimics one expected after a bottleneck; again, the calculated distribution does not follow such a pattern. Finally, there may be a reduction in the substitution rate in the control region of mtDNA in crocodilians when compared with other vertebrates. The sequences presented here as well those of other crocodilians suggest that this may indeed be the case.

Using sequences taken from Ray and Densmore (2002) we estimated the sequence divergence between Osteolaemus and all members of Crocodylus (accession numbers AF460207-AF460215, AF461417 and AF460218) using the HKY85 model and incorporating a gamma correction of 0.1911 as suggested by Modeltest v3.06 (Posada and Crandall 1998). The average divergence was calculated to be 0.208 . Brochu $(2000,2001)$ has suggested a minimum divergence between Osteolaemus and Crocodylus at 19 mya. After assuming

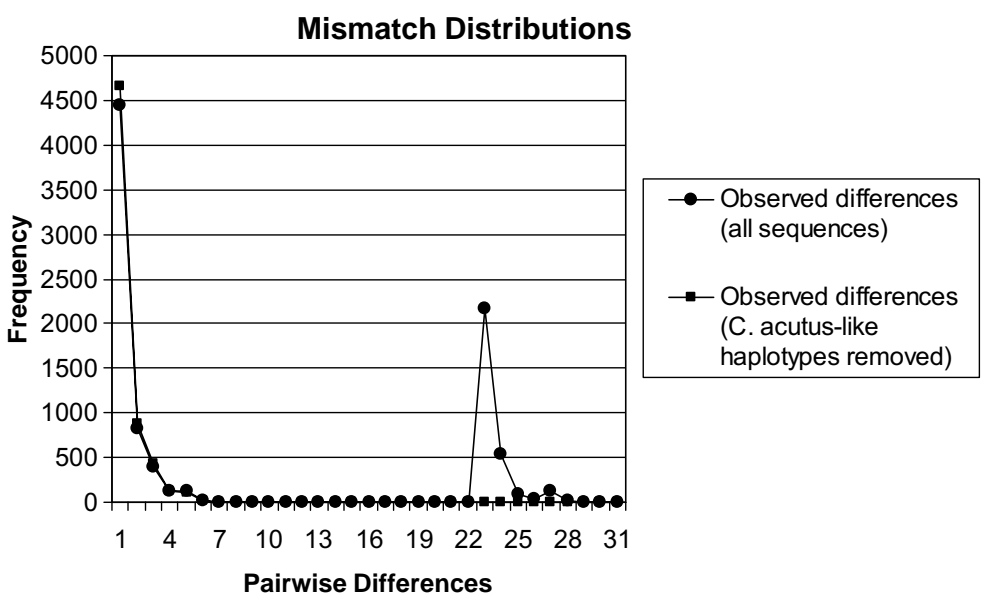

Figure 4. Mismatch distributions of pairwise sequence differences in mtDNA control region sequences from C. moreletii. The number of mismatches is given on the horizontal axis and the frequency in each category is represented on the vertical axis. 
Table 4. Pairwise HKY85 distance estimates for comparisons among ten Crocodylus species using control region sequence data

\begin{tabular}{|c|c|c|c|c|c|c|c|c|c|c|}
\hline & C. $a c u$ & C. $\min$ & C. nil & C.por & C.pal & C. mor & C. john & C. int & C. rhom & C. siam \\
\hline C. acutus & - & & & & & & & & & \\
\hline C. mindorensis & 0.062 & - & & & & & & & & \\
\hline C. niloticus & 0.049 & 0.060 & - & & & & & & & \\
\hline C. porosus & 0.061 & 0.074 & 0.063 & - & & & & & & \\
\hline C. palustris & 0.054 & 0.081 & 0.068 & 0.054 & - & & & & & \\
\hline C. moreletii & 0.034 & 0.079 & 0.059 & 0.066 & 0.073 & - & & & & \\
\hline C. johnsoni & 0.081 & 0.065 & 0.074 & 0.081 & 0.084 & 0.101 & - & & & \\
\hline C. intermedius & 0.008 & 0.069 & 0.052 & 0.056 & 0.059 & 0.030 & 0.086 & - & & \\
\hline C. rhombifer & 0.038 & 0.074 & 0.054 & 0.070 & 0.065 & 0.052 & 0.086 & 0.043 & - & \\
\hline C. siamensis & 0.065 & 0.083 & 0.065 & 0.070 & 0.054 & 0.078 & 0.084 & 0.070 & 0.075 & - \\
\hline
\end{tabular}

Sequences are taken from Ray and Densmore (2002).

this divergence time, we arrived at a substitution rate of $1.09 \times 10^{-8}$. This value is 5.4 times lower than the value typically cited for mammals $\left(5.9 \times 10^{-8}\right.$; Brown et al. 1982). Assuming a more recent divergence for the genus Crocodylus of 12 mya (Brochu, pers. comm.) and calculating the mean divergence (0.199) between C. cataphractus and other members of the genus allows us to arrive at an estimated rate of $1.66 \times 10^{-8}, 3.6$ times lower than the standard mammalian rate. If either of these rates of change is accurate, lower estimates of mtDNA nucleotide diversity may be expected when using control region sequences to examining crocodylian populations.

\section{Population structure}

The initial $F_{\mathrm{ST}}$ estimate $(0.28)$ raised the possibility that there may be significant subdivision among the locales sampled. It should be noted, however, that with the exception of Peten in Guatemala, Banana Bank Lagoon is the only locale to show high levels of differentiation from other sampled locales (Table 3). This is similar to results that Dever et al. (2002) recovered using nine microsatellite loci. While it is true that a reduction in statistical power probably accompanied our switch to a mtDNA marker, adding sequence data may have clarified why this population appeared to fit the isolation by distance model in the original microsatellite analyses (Dever et al. 2002). We hypothesize that the introgression of Crocodylus acutus genes into several populations (see below), especially in
Banana Bank Lagoon, may have confounded the situation with regard to the microsatellite data. When we removed the haplotypes characteristic of C. acutus from the data set, our estimate of $F_{\mathrm{ST}}$ was reduced to 0.06 . Thus, the isolation by distance model of genetic differentiation may not be appropriate for explaining population patterns in C. moreletii and further investigation is warranted.

Three of the 20 unique haplotypes were located exclusively in the Peten, Guatemala sample, raising the possibility that this population has differentiated genetically from the others. This population was indeed determined to be significantly different from New River, New River Lagoon and Gold Button Lagoon based on haplotype frequencies (Table 3). However, the distribution of these three haplotypes on the neighbor-joining tree did not support any phylogeographic pattern and results from the Mantel tests support this interpretation.

While it is interesting to note $F_{\mathrm{ST}}$ reductions when comparing Banana Bank Lagoon, Peten and the remaining populations, these results must be interpreted with caution because of large differences in sample size between the two populations and others. This is especially true in the case of Banana Bank Lagoon after removal of the C. acutus-like haplotypes from the data set. These two factors introduce the specters of sampling bias and reduction in statistical power. Thus, the C. moreletii-like haplotype data appear to give no substantial evidence of phylogeographic structure and little information with regard to possible population substructuring in the Yucatan 
Peninsula. However, the Guatemalan population should be further investigated.

\section{Possible hybridization}

Hybridization between C. moreletii and C. acutus has long been postulated (Ross and Ross 1974; Ross and Mayer 1983). Typically, specimens of C. moreletii have five to six scales in each transverse dorsal scale row and exhibit irregular scale groups on both the ventral and lateral surfaces of the tail (Brazaitis 1973; Ross and Ross 1974; Ross and Mayer 1983) while specimens of C. acutus exhibit fewer scales in each dorsal scale row and regular scale groups on the tail. Crocodiles with characteristics of both species have been reported from coastal regions of Mexico (Powell 1972) and Belize (Schmidt 1924; Abercrombie et al. 1980; Platt and Thorbjarnarson 1997; Sigler 1998). These individuals typically exhibit a reduced number of dorsal scales in each transverse row, and reduced or absent subcaudal scale irregularities. In an examination of museum specimens of $C$. acutus collected from throughout its range, Ross and Ross (1974) found irregular scale groups on the lateral surface of the tail only where $C$. acutus was sympatric with $C$. moreletii (Belize through Chiapas, Mexico), or where the population may have been influenced by feral $C$. moreletii (west coast of Mexico). The dorsal armor of the suspected hybrids resembled both parent species (Ross and Ross 1974). In addition, preliminary microsatellite analyses of sympatric animals from both species have suggested that hybridization may be occurring (E. Hekkala and G. Amato pers. comm.). Therefore, both Morelet's crocodile and American crocodile populations that have been characterized as 'pure' warrant vigorous protection.

The average genetic distance between the clades 1 and 2 of Figure 2 was 0.055 , a value typical of interspecific comparisons in other species of Crocodylus (Ray et al. 2001, and Table 4). Haplotypes in the lower clade include animals from Banana Bank Lagoon, within the Belize River drainage, and populations associated with the New River drainage of north-central Belize. The presence of $C$. acutus haplotypes in presumed $C$. moreletii habitat raises the question of whether or not the animals with $C$. acutus haplotypes are hybrids, immigrant American crocodiles from the coastal regions of Belize, or both.
While subadult animals of the two species are often difficult to distinguish from a distance in the field, ventral and nuchal scale patterns are generally reliable diagnostic characters (Brazaitis 1973). Unfortunately, voucher photographs taken of most animals were from inappropriate angles and these scale patterns were not always visible. We have, however, obtained photographs of several animals sampled from Banana Bank showing ventral scale patterns. Three animals (4575-4577) examined at Banana Bank in July 2002 were phenotypically similar to $C$. moreletii. Two of these animals had $C$. acutus-like haplotypes, 4575 and 4577. One crocodile (4675) exhibited a reduced number of scales ( $<5$, typical of $C$. acutus) in each transverse dorsal row, and irregular scale groups were present only on the lateral surface of the tail.

Obviously, a more extensive study of the morphology of animals considered potential hybrids must be performed. Our results, however, do suggest hybridization. The identification of Crocodylus acutus haplotypes in or close to main river channels suggests an avenue for introgression into C. moreletii habitat. Three of the suspected hybrids collected in the New River drainage were males nearing sexual maturity (total length $[\mathrm{TL}]=167-189 \mathrm{~cm}$, Platt and Thorbjarnarson 2000b), suggesting that male $C$. acutus could have traveled inland from the coast via New River or that hybrid offspring from a $C$. acutus female migrated into the area. While the former situation is possible, SGP, TRR, and AGF have collected Morelet's crocodiles along the New River for over ten years ( $\sim 400$ animals) and have found no evidence of purebred $C$. acutus invading this river system, however it is possible that some $C$. acutus immigrants were missed. We suggest that a more likely explanation is backcrossing between hybrids formed initially near the coast and purebred C. moreletii farther inland. Regardless of their origin both their size and presence in $C$. moreletii habitat suggest that they may eventually establish territories as breeding adults and that any future offspring from these individuals and $C$. moreletii females in the area will be hybrids.

The existence of potential hybrids at Banana Bank could also be explained by backcrossing. All crocodiles captured at this locale were juveniles $(\mathrm{TL}=54-99 \mathrm{~cm})$. Most were approximately the same size, with only a few being slightly larger than the others. The small size of these animals 
does not lend support to a long ( $\sim 36 \mathrm{~km}$ overland or $\sim 67 \mathrm{~km}$ via the Belize River) migration from the coast. Instead, these size measurements suggest these are members of a single or two successive cohorts from at least one breeding female. We cannot determine if the maternal parent(s) was "pure" Crocodylus acutus but the lack of definitive morphological characters identifying animals 4575 and 4577 (both bear C. acutus-like haplotypes but display primarily $C$. moreletii scalation) suggest that if they are hybrids, the cross-species interaction may have occurred two or more generations previous to this one. Backcrossing between the initial hybrids and C. moreletii could erase most of the phenotypic characters passed from the C. acutus ancestor while allowing the haplotype to remain intact through maternal transmission. It may be that some low level of hybridization has always occurred where the two species are sympatric and that what we have observed is typical of the species' interaction.

\section{Conclusions and implications}

There are several potentially critical conservation issues that must be considered in light of our findings. Platt and Thorbjarnarson (1997) observed possible hybrids of C. acutus and C. moreletii in the coastal regions of southern Belize, but not in central or northern Belize. Our discoveries of C. acutus haplotypes in Banana Bank and the New River drainage indicate that there may be considerably more genetic contact between these species than was previously recognized. Crocodylus moreletii has here-to-fore been considered one of the least endangered of those crocodilians currently listed on Appendix I of CITES and Platt and Thorbjarnarson (2000b) suggested that an endangered classification is no longer warranted. If hybridization is indeed occurring, however, it may be that genetically pure $C$. moreletii in Belize are rarer than previously assumed and it is of the utmost importance that this species not be removed from Appendix I until the degree of interspecific genetic contact has been accurately assessed. Those Morelet's crocodile populations that have been identified as genetically pure (e.g., the Macal River system in Belize and possibly the Guatemalan and Mexican populations) should also be vigorously protected.
A potentially more important issue, however, is the threat introgression from $C$. moreletii may represent to Belizean C. acutus populations. The recovery of C. acutus from the hunting pressures of the 1950s and 1960s has been slower than for C. moreletii (Platt and Thorbjarnarson 2000a). Thus, it is likely that high levels of hybridization represent a larger danger to the genetic integrity of $C$. acutus than to C. moreletii in Belize. It is therefore critical that a comparable study of nuclear and mitochondrial markers in C. acutus be performed to determine if the introgression observed is "one-way" or "two-way" in nature. A study of microsatellite variation in Central American $C$. acutus populations is currently being conducted by LDD that and colleagues should help provide an answer to this question.

The results of our study indicate that while there is some minor evidence of population differentiation in Crocodylus moreletii the issue deserves more attention and it is critical that future studies increase sampling outside of Belize. Dever et al. (2002) attributed the differentiation between Banana Bank Lagoon and those populations in North-central Belize to isolation-by-distance. The mtDNA data presented herein indicate that this level of differentiation may be due (at least in part) to the introduction of foreign alleles from $\mathrm{C}$. acutus into the Banana Bank Morelet's crocodile population. This result emphasizes the need for multiple markers in such studies, even if sampled populations are a priori thought to be "pure". Furthermore, local conservation and management efforts designed for either $C$. moreletii or $C$. acutus should incorporate protocols that allow the genetic heritage of their animals to be accurately determined. It is now clear that range alone cannot always accurately predict the genetic makeup of crocodile populations found in every locality.

\section{Acknowledgements}

We would like to thank the following individuals and organizations for their help with this project. Scientific research permits were issued by the Conservation Division of the Ministry of Natural Resources, Belmopan, Belize. R. Bradley, R. Baker, and R. Strauss contributed valuable advice and equipment support for the completion of analyses. D. Rodriguez provided valuable technical assistance. 
M. de Anaya and E. Bermingham of the Smithsonian Tropical Research Institute kindly provided tissues from Tabasco, Mexico and Peten, Guatemala. The Graduate School and the Department of Biological Sciences at Texas Tech University (specifically, C. Phillips and J. Zak) provided financial support to DAR and LDD. We also thank Mark and Monique Howells, Lamanai Outpost Lodge and Lamanai Field Research Center in Belize for logistical support. Comments on previous versions of this manuscript were provided by Abdel Halim-Salem. This work was funded in part by the National Geographic Society (\#6529-99, \#7007-01) to LDD, the Louisiana Board of Regents Governor's Biotechnology Initiative GBI (2002-005) to MAB, the US Environmental Protection Agency (\#R826310) to STM, the Royal Geographical Society (TRR), and the ARCS Foundation, Lubbock, Texas (TRR). Support for SGP was provided by the Wildlife Conservation Society and Oglala Lakota College.

\section{References}

Abercrombie CL, Davidson D, Hope CA, Scott DE (1980) Status of Morelet's crocodile (Crocodylus moreletii) in Belize. Biol. Cons., 17, 103-113.

Abercrombie CL, Davidson D, Hope CA, Scott DE, Lane JE (1982) Investigations into the status of Morelet's crocodile Crocodylus moreletii in Belize, 1980. In: Crocodiles, Proceedings 5th Working Meeting of the Crocodile Specialist Group, pp. 11-30. IUCN - The World Conservation Union, Morges, Switzerland.

Adams SE, Smith MH, Baccus R (1980) Biochemical variation in the American alligator. Herpetologica, 36, 289-296.

Avise JC, Bowen BW, Lamb T, Meylan AB, Bermingham E (1992) Mitochondrial DNA evolution at a turtle's pace: Evidence for low genetic variability and reduced microevolutionary rate in the Testudines. Mol. Biol. Evol., 9, 457-473.

Baker AJ, Marshall HD (1997) Mitochondrial control region sequences as tools for understanding evolution. In: Avian Molecular Evolution and Systematics (ed. Mindell D), pp. 5182. Academic Press, San Diego.

Bandelt H-J, Forster P, Röhl A (1999) Median-joining networks for inferring intraspecific phylogenies. Mol. Biol. Evol., 16, 37-48.

Barrowclough GF, Gutierrez RJ, Groth JG (1999) Phylogeography of spotted owl (Strix occidentalis) populations based on mitochondrial sequences: Gene flow, genetic structure, and a novel biogeographic pattern. Evolution, 53, 919-931.

Brazaitis P (1973) The identification of living crocodilians. Zoologica, 58, 59-88.

Brochu C, Densmore LD (2001) Crocodile phylogenetics: A review of current progress. In: Crocodilian Biology and Evolution (eds. Grigg G, Seebacher F, Franklin C), pp. 3-8. Surrey Beatty and Sons, Chipping Norton.
Brochu CA (2000) Phylogenetic relationships and divergence timing of Crocodylus based on morphology and the fossil record. Copeia, 2000, 657-673.

Brown WM, Prager EM, Wang A, Wilson AC (1982) Mitochondrial DNA sequences of primates: Tempo and mode of evolution. Proc. Natl. Acad. Sci, USA, 76, 1976-1971.

Charnock-Wilson J (1970) Manatees and crocodiles. Oryx, 10, 236-238.

Cicero C, Johnson NK (1998) Molecular phylogeography and ecological diversification in a clade of New World songbirds (genus Vireo). Mol. Ecol., 7, 1359-1370.

Crochet P-A, Desmarais E (2000) Slow rate of evolution in the mitochondrial control region of gulls. Mol. Biol. Evol., 17, 1797-1806

Davis LM, Glenn TC, Elsey RM, Brisbin IL, Dessauer HC, Sawyer RH (2001a) Genetic structure of six populations of American alligators: A microsatellite analysis. In: Crocodilian Biology and Evolution (eds. Grigg G, Seebacher F, Franklin C), pp. 38-50. Surrey Beatty and Sons, Chipping Norton.

Davis LM, Glenn TC, Elsey RM, Dessauer HC, Sawyer RH (2001b) Multiple paternity and mating patterns in the American alligator, Alligator mississippiensis. Mol. Ecol., 10, 1011-1024.

Davis LM, Glenn TC, Strickland DC, Guillette LJ, Elsey RM, Rhodes WE, Dessauer HC, Sawyer RH (2002) Microsatellite DNA analyses support an east-west phylogeographic split of American alligator populations. J. Exp. Zool., 294, 352-372.

Dawson MN, Staton JL, Jacobs DK (2001) Phylogeography of the tidewater goby, Eucyclogobius newberryi (Teleostei, Gobiidae), in coastal California. Evolution, 55, 1167-1179.

Densmore LD, Owen RD (1989) Molecular systematics of the order Crocodilia. Am. Zool., 29, 831-841.

Densmore LD, White PS (1991) The systematics and evolution of the Crocodilia as suggested by restriction endonuclease analysis of mitochondrial and nuclear ribosomal DNA. Copeia, 1991, 602-615.

Dever JA, Densmore LD (2001) Microsatellites in Morelet's crocodile Crocodylus moreletii and their utility in addressing crocodilian population genetics questions. J. Herp., 35, 542544.

Dever JA, Strauss RE, Rainwater TR, McMurry ST, Densmore LD (2002) Genetic diversity, population structure and gene flow in Morelet's crocodile (Crocodylus moreletii) from Belize, Central America. Copeia, 2002(4), 1078-1091.

Donovan MF, Semlitsch RD, Routman EJ (2000) Biogeography of the southeastern United States: A comparison of salamander phylogeographic studies. Evolution, 54, 14491456.

Encalada SE, Lahanas PN, Bjorndal KA, Bolten AB, Miyamoto MM, Bowen BW (1996) Phylogeography and population structure of the Atlantic and Mediterranean green turtle Chelonia mydas: A mitochondrial DNA control region assessment. Mol. Ecol., 5, 473-483.

FitzSimmons N, Tanksley S, Forstner MR, Louis EE, Daglish R, Gratten J, Davis S (2001) Microsatellite markers for Crocodylus: New genetic tools for population genetics, mating system studies and forensics. In: Crocodilian Biology and Evolution (eds. Grigg G, Seebacher F, Franklin C), pp. 51-57. Surrey Beatty and Sons, Chipping Norton.

FitzSimmons NN, Buchan JC, Lam PV, Polet G, Hung TT, Thang NQ, Gratten J (2002) Identification of purebred Crocodylus siamensis for reintroduction in Vietnam. J. Exp. Zool., 294, 373-381. 
Fleischer RC, Perry EA, Muralidharan K, Stevens EE, Wemmer CM (2001) Phylogeography of the Asian elephant Elaphas maximus based on mitochondrial DNA. Evolution, 55, 1882-1892.

Funk DJ, Omland KE (2003) Species-level paraphyly and polyphyly: Frequency, causes, and consequence, with insights from animal mitochondrial DNA. Annu. Rev. Ecol. Evol. Syst., 34, 397-423.

Gartside DF, Dessauer HC, Joanen T (1977) Genic homozygosity in an ancient reptile (Alligator mississippiensis). Biochem. Genet., 15, 655-663.

Gatesy J, Amato GD (1992) Sequence similarity of 12S ribosomal segment of mitochondrial DNAs of Gharial and False Gharial. Copeia, 1992, 241-243.

Glenn TC, Dessauer HD, Braun MJ (1998) Characterization of microsatellite DNA loci in American alligators. Copeia, 1998, 591-601.

Glenn TC, Staton JL, Vu AT, Davis LM, Alvarado Bremer JR, Rhodes WE, Brisbin Jr IL, Sawyer RH (2002) Low mitochondrial DNA variation among American alligators and a novel non-coding region in crocodilians. J. Exp. Zool., 294, $312-324$.

Hall TA (1999) BioEdit: A user-friendly biological sequence alignment editor and analysis program for Windows 95/98/ NT. Nucleic Acids Symp. Ser., 41, 95-98.

Hasegawa M, Kishino H, Yano T (1985) Dating the human-ape split by a molecular clock of mitochondrial DNA. J. Mol. Evol., 22, 160-174.

Hoffmann FG, Baker RJ (2001) Systematics of the genus Glossophaga Chiroptera: Phyllostomidae and phylogeography in $G$. soricina based on the cytochrome $b$ gene. J. Mamm., 82, 1092-1101.

Jensen-Seaman MI, Kidd KK (2001) Mitochondrial DNA variation and biogeography of eastern gorillas. Mol. Ecol., 10, 2241-2247.

Kotlik P, Berrebi P (2001) Phylogeography of the barbell Barbus barbus assessed by mitochondrial DNA variation. Mol. Ecol., 10, 2177-2185.

Lahanas PN, Miyamoto MM, Bjorndal KA, Bolten AB (1994) Molecular evolution and population genetics of greater Caribbean green turtles (Chelonia mydas) as inferred from mitochondrial control region sequences. Genetica 94, 57-67.

McMillan WO, Palumbi SR (1997) Rapid rate of control-region evolution in Pacific butterflyfishes Chaetodontidae. J. Mol. Evol., 45, 473-484.

Mantel N (1967) The detection of disease clustering and a generalized regression approach. Cancer Res., 27, 209-220.

Maruyama T, Fuerst PA (1984) Populations bottlenecks and nonequilibrium models in population genetics I. Allele numbers when populations evolve from zero variability. Genetics, 108, 745-763.

Maruyama T, Fuerst PA (1985) Populations bottlenecks and nonequilibrium models in population genetics II. Number of alleles in a small population that was formed by a recent bottleneck. Genetics, 111, 675-689.

Menzies RA, Kushlan J, Dessauer HC (1979) Low degree of genetic variability in the American alligator (Alligator mississippiensis). Isozyme Bull., 12, 61.

Milot E, Gibbs HL, Hobson KA (2000) Phylogeography and genetic structure of northern populations of the yellow warbler (Dendroica petechia). Mol. Ecol., 9, 667-681.

Nielson M, Lohman K, Sullivan J (2001) Phylogeography of the tailed frog Ascaphus truei: Implications for the biogeography of the Pacific Northwest. Evolution, 55, 147-160.
Nei M (1987) Molecular Evolutionary Genetics. Columbia University Press, New York.

Page RDM (1996) TREEVIEW: An application to display phylogenetic trees on personal computers. Comput. Appl. Biosci., 12, 357-358.

Platt S (1996) The Ecology and Status of Morelet's Crocodile in Belize. Ph.D. thesis, Clemson University.

Platt SG, Thorbjarnarson JB (1997) Status and Life History of the American Crocodile in Belize. Belize Coastal Zone Management Project BZE/92/G31. Report to United Nations Development Programme, Global Environmental Facility, Belize City, Belize. 163 pp.

Platt SG, Thorbjarnarson JB (2000a) Population status and conservation of Morelet's crocodile, Crocodylus acutus, in northern Belize. Biol. Cons., 96, 13-20.

Platt SG, Thorbjarnarson JB (2000b) Population status and conservation of Morelet's crocodile, Crocodylus moreletii, in northern Belize. Biol. Cons., 96, 21-29.

Posada D, Crandall KA (1998) MODELTEST: Testing the model of DNA substitution. Bioinformatics, 14, 817-818.

Powell J (1972) The Morelet's crocodile: An unknown quantity. Animal Kingdom, 1972(2), 21-26.

Ramos R, de Buffrenil V, Ross JP (1994) Current status of the Cuban crocodile, Crocodylus rhombifer, in the wild. In: Crocodiles, Proceedings of the 12th Working Meeting of the Crocodile Specialist Group, pp. 113-140. IUCN, Gland, Switzerland.

Randi E, Lucchini V (1998) Organization and evolution of the mitochondrial DNA control region in the avian genus Alectoris. J. Mol. Evol., 47, 449-162.

Ray DA, White PS, Duong HV, Cullen T, Densmore LD (2001) High levels of variation in the African dwarf crocodile $O s$ teolaemus tetraspis. In: Crocodilian Biology and Evolution (eds. Grigg G, Seebacher F, Franklin C), pp. 58-69. Surrey Beatty and Sons, Chipping Norton.

Ray DA, Densmore LD (2002) The crocodilian mitochondrial control region: General structure, conserved sequences and evolutionary implications. J. Exp. Zool., 294, 334-345.

Rogers AR, Harpending H (1992) Population growth makes waves in the distribution of pairwise genetic differences. Mol. Biol. Evol., 9, 552-569.

Roman J, Santhuff SD, Moler PE, Bowen BW (1999) Population structure and cryptic evolutionary units in the alligator snapping turtle. Conserv. Biol., 13, 135-142.

Rooney AP, Honeycutt RL, Derr JN (2001) Historical population size change of bowhead whales inferred from DNA sequence polymorphism data. Evolution, 55, 1678-1685.

Ross CA, Ross FD (1974) Caudal scalation of Central American Crocodylus. Proc. Biol. Soc. Wash., 87, 231-234.

Ross FD, Mayer GC (1983) On the dorsal armor of the Crocodilia. In: Advances in Herpetology and Evolutionary Biology (eds. Rhodin AGJ, Miyata K), pp. 305-331. Museum Comp. Zool., Cambridge.

Ross JP (1998) Crocodiles: An Action Plan for their Conservation, IUCN/SSC Crocodile Specialist Group Publ., Oxford Press, Oxford.

Sambrook J, Fritsch EF, Maniatis T (1989) Molecular Cloning: A Laboratory Manual, 2nd edn. Cold Spring Harbor Laboratory Press, New York.

Schmidt KP (1924) Notes on Central American crocodiles. Fieldiana, 12, 79-92.

Schneider S, Roessli D, Excoffier L (2000) Arlequin ver. 2000: A software for population genetics data analysis. Genetics and Biometry Laboratory,University of Geneva, Switzerland. 
Sigler L (1998) A Crocodylus acutus with the appearance of a $C$. moreletii. Crocodile Specialist Group Newsletter, 173, 9-11.

Swofford DL (1998) PAUP Phylogenetic Analysis Using Parsimony, version $4.01 \mathrm{~b}$.

Vilà C, Amorim IR, Leonard JA, Posada D, Castroviejo J, Petrucci-Fonseca F, Crandall KA, Ellegren H, Wayne RK (1999) Mitochondrial DNA phylogeography and population history of the grey wolf Canis lupus. Mol. Ecol., 8, 20892103.
Walker D, Avise JC (1998) Principles of phylogeography as illustrated by freshwater and terrestrial turtles in the southeastern United States. Ann. Rev. Ecol. Syst., 29, 2358.

Wright S (1978) Evolution and the genetics of populations. Vol. 4. Variability within and among natural populations. University of Chicago Press, Chicago. 